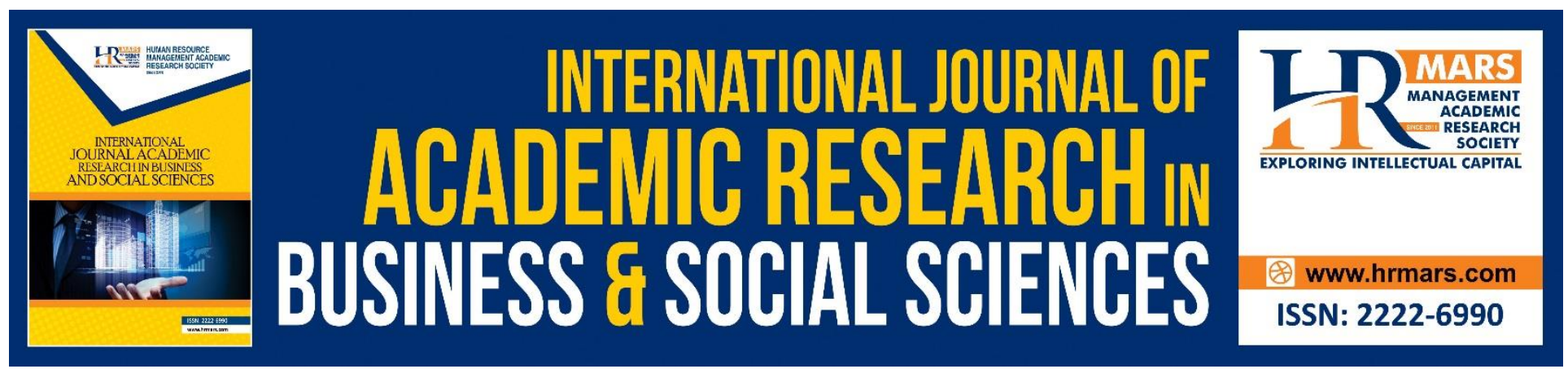

\title{
Rehabilitation of Children Beyond Control in Malaysia: Towards Deinstitutionalization
}

\author{
Shariffah Nuridah Aishah Syed Nong \\ Jal Zabdi Mohd Yusoff
}

To Link this Article: http://dx.doi.org/10.6007/IJARBSS/v9-i3/5705

DOI: $\quad 10.6007 /$ IJARBSS/v9-i3/5705

Received: 07 Feb 2019, Revised: 26 Feb 2019, Accepted: 16 March 2019

Published Online: 29 March 2019

In-Text Citation: (Nong \& Yusoff, 2019)

To Cite this Article: Nong, S. N. A. S., \& Yusoff, J. Z. M. (2019). Rehabilitation of Children Beyond Control in Malaysia: Towards Deinstitutionalization. International Journal of Academic Research in Business and Social Sciences, 9(3), 449-459.

Copyright: (C) 2019 The Author(s)

Published by Human Resource Management Academic Research Society (www.hrmars.com)

This article is published under the Creative Commons Attribution (CC BY 4.0) license. Anyone may reproduce, distribute, translate and create derivative works of this article (for both commercial and non-commercial purposes), subject to full attribution to the original publication and authors. The full terms of this license may be seen

at: http://creativecommons.org/licences/by/4.0/legalcode

Vol. 9, No. 3, 2019, Pg. 449 - 459

http://hrmars.com/index.php/pages/detail/IJARBSS

JOURNAL HOMEPAGE

Full Terms \& Conditions of access and use can be found at http://hrmars.com/index.php/pages/detail/publication-ethics 


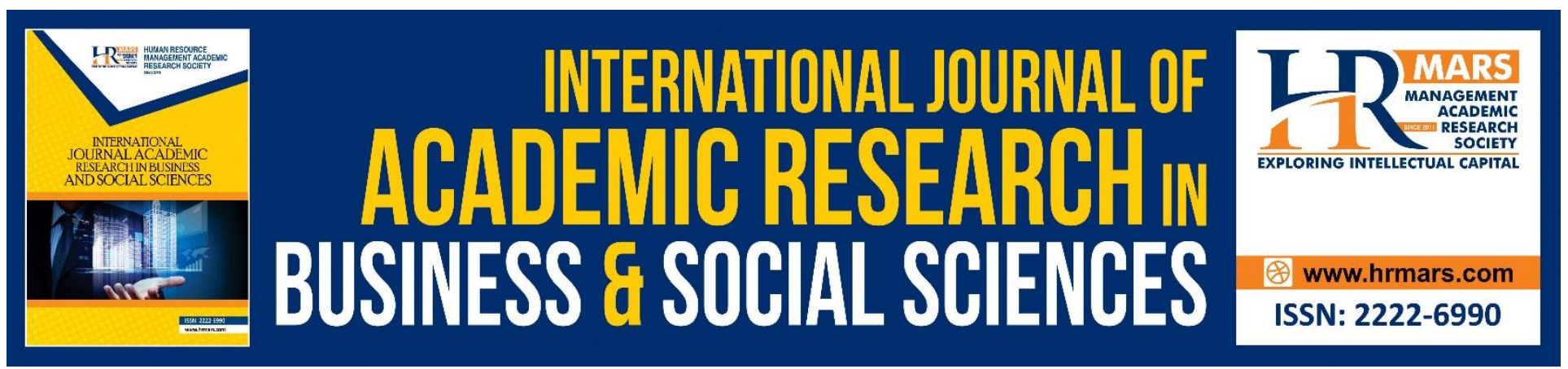

\title{
Rehabilitation of Children Beyond Control in Malaysia: Towards Deinstitutionalization
}

\author{
Shariffah Nuridah Aishah Syed Nong
}

PhD student, Faculty of Law, University of Malaya, 50603, Kuala Lumpur, Malaysia \& Senior Lecture,

Faculty of Law and International Relations, Sultan Zainal Abidin University, 21300, Terengganu, Malaysia.

\author{
Jal Zabdi Mohd Yusoff
}

Associate Professor, Faculty of Law, University of Malaya, 50603, Kuala Lumpur, Malaysia

\begin{abstract}
Background: Placement in institutions has once been the most popular rehabilitative measures for children beyond control in Malaysia. It has been enforced through the court's order since British colonisation and continues until today. Throughout the historical development, children beyond control were sent to various institutional settings including the approved schools, probation hostels, place of refuge, privately-owned centres, and Henry Gurney Schools. However, this practice was criticised since it contradicts the United Nations Convention on the Rights of the Child's principle which places institutionalisation as the last resort in the rehabilitation of children. Prior researches indicate that institutionalisation raises the issues of, inter-alia, stigma, deterioration of family relationship and interruption of academic development. Acknowledging the importance of family involvement in rehabilitating the children, the Child Act 2001 was amended recently with the objective, among others, to introduce family-based care. Therefore, this study is conducted to analyse the legal development of institutionalisation of children beyond control in Malaysia and the effect of the Child Act (Amendment) 2016 on institutionalisation of the children. This study is carried out through library research and semi-structured interviews with those involved directly in handling children beyond control cases including the officers of the Department of Social Welfare, probation officers and officers in charge of the probation hostels. The study found that despite of the heavy reliance made to the institutions for rehabilitation of children beyond control, institutionalisation has been reduced recently through the introduction of family-based care by the Child Act (Amendment) 2016.
\end{abstract}




\section{Introduction}

Welfare service in Malaysia began after the World War II. Prior to the war, social problems were usually handled by the respective tribes, charitable individuals and religious organisations (Sushama, 1992). There was no system, legislations or correctional institutions to put the Malay youths who committed offences or misbehaviour under disciplinary procedure (Rashid, 2009; Triantafillou \& Moreira, 2002). However, according to Triantafillou and Moreira (2002), delinquent children were sent to the Reformatory School in Singapore for rehabilitation from the early 1920s. The Juvenile Delinquency and Juvenile Welfare Committee (which proposed for the Juvenile Court Ordinance 1947) reported that the absence of delinquency laws especially before the Japanese occupation was due to the small number of cases occurred at that time (Report of the Juvenile Delinquency and Juvenile Welfare Committee, 1947).

After the World War II, institutional based rehabilitation was introduced in Malaysia. It was shaped by several factors including the British involvement, Islamic teachings, and distinctive geographical and population features, and formed as a reaction to the social upheaval which occurred as a result of the disturbance of balance in multi-racial Malaysian community during the transitional process from traditional to industrial society (Bee, n.d.). In other words, the English originated rehabilitation system of the delinquent children was shaped based on the demands of the various ethnic groups in the society (Villarante, 2005). Among the laws pertaining to the care and control of children which originates from the era were the Juvenile Courts Act 1947, the Juvenile Court (Places of Detention Regulations) 1950, the Children and Young Persons Act 1947 and the Adoption 1952 and Adoption Registration 1953 Ordinances (Bee, n.d.).

The Juvenile Delinquency and Juvenile Welfare Committee explained that institutional establishment is necessary to prevent delinquency which stems from the home environment by removing the children from those conditions (Report of the Juvenile Delinquency and Juvenile Welfare Committee, 1947). It is further reported that in nine out of ten cases, delinquency arises from lack of decent home and environment, and not from hidden criminal tendencies. The Committee which was appointed to prepare proposal to the Malayan Union government on the necessary steps to handle delinquency (criminal and non-criminal behavior) therefore suggested, among others, for the establishment of juvenile court system, probation system, remand homes, approved schools, juvenile welfare committee in all main cities, and boys camp based on the United Kingdom's experience. United Kingdom already has a thorough systems of juvenile court, supervision, temporary detention homes, approved schools and others since the early 20s (Rashid, 2009; Triantafillou \& Moreira, 2002). The end of 90s witnessed the establishment of several institutions with the aim to change the youths to disciplined, healthy and productive individuals through educational system (Triantafillou \& Moreira, 2002).

Steps taken towards deinstitutionalization may be seen as early as 1947. Despite the role of the institutions to rehabilitate children with misbehavior, the courts were reminded to apply the legal provisions wisely and order for institutional placement as the last choice. During the presentation of the Juvenile Courts Bill 1947, the Attorney General had stated that: 
"There is a tendency amongst Presiding Officers in the United Kingdom as well as here to regard Homes as the solution of the delinquency problem. But the Home should be the last not the first resort. To condemn a child to an institution is to deprive it of the pleasures and uncertainties of family life. No Court should commit a child to an approved school without very careful consideration and study of the child's background and problems...The making of an Approved School Order is the most serious decision which a Juvenile Court can take" (The Juvenile Courts Bill, 1947).

Apart from the reminder, the national Community Care Policy known as "Dasar Masyarakat Penyayang" introduced by the government in 1960 also supports deinstitutionalization by encouraging active participation from the welfare service receivers including the children ( $R$. Nalasamy \& Abu Bakar Ah, 2013). This policy had reduced institutional based service through the activation of community care service whereby social workers were encouraged to work with children in family or local community environment (R. Nalasamy \& Abu Bakar Ah, 2013). Guan Bee (n.d), who was a principal of the Juvenile Home Boys during the implementation of the Juvenile Courts Act 1947 in his presentation, highlighted that Malaysia encourages community rehabilitation and places institutional treatment as the last choice. According to him, the institutional placement of children is subjected to several limitations for example, those who are below 10 years old cannot be sent to the approved schools or probation hostels, and those who are below 14 years cannot be detained in Henry Gurney School. Meanwhile, R. Nalasamy and Abu Bakar Ah (2013) observed that the children welfare service system has in fact been shifted from "necessity-based approach" to "rights-based approach" due to the failure of the former to respect children's rights. The former approach provides services to the children only after the social workers identify the lack in children's need. On the other hand, the later approach in recognizing children's rights, supports institutional care as the last resort for those with problematic behavior whereby it can be suggested only if the family or society fails in supervising or controlling them. In addition, the children placed in the institutions are entitled to be dealt with respect and the service given should be based on their best interests.

\section{Who are Children beyond Control?}

Children beyond control are simply those who are beyond the control of the parents or guardians. They are locally known as naughty, ungovernable, disobedient, delinquent, deviant, or children involved in social problems (Akram, 2007; Haji Ali, 2006; Hamzah, Mustafa, \& Che Din, 2011; Najmuddin, 2003; Yahaya, Yahaya, \& Bachok, 2010). Examples of beyond control behaviour commonly committed are school truancy, running away from home, coming home late, involving in immoral behaviour, consumption of alcohol and smoking. The list is however not exhaustive since new misbehaviour may be committed from time to time. For example, United States of America has added a new status offence called "the baggy pants ordinances" as a result of a fashion trend among the youngsters who wore sagging pants that expose the top of their boxer shorts near the waist (Matthews, 2000). Nonetheless, not all mere disobedient constitutes "beyond control". According to Theoharis (n.d.), there are three components that have to be fulfilled; firstly, the behaviour must be regularly committed, secondly, the behaviour has a disturbing or harm element which threatens the welfare, harmony or safety of the environment and thirdly, the command by the parents must be lawful. Therefore, children who refuse to abide by the school rules are disturbing the school 
environment, and it is insufficient if the children only refuse to eat vegetables or sleep on time as requested by the parents. Likewise, it is not beyond control if the parents make illegal command such as forcing children to commit crimes or do something which will cause harm to the children.

At the international level, beyond control behaviour forms part of "status offences" in some countries like United States of America, Japan and Nigeria whereby the doer is called "status offender". Status offence refers to the behaviour which is illegal if committed by the children only but not by the adults ('Age Discrimination: Global Report on Status Offences', 2009; 'Innocenti Digest 3: Juvenile Justice', n.d.; Cantwell, 1998; US Legal Dictionary, n.d.; Britannica Encyclopedia, n.d; Michon, n.d.; Kim, 2010). In simple words, it is a non-criminal behaviour committed by children and accordingly must be distinguished from delinquency. This is because delinquent children are defined as those who commit unlawful offence that is punishable if committed by adults such as stealing, beating and murdering. (Black's Law Dictionary, n.d; Britannica Encyclopedia, n.d.; Champion, 2007; Kim, 2010; Sherman and Blitzman, 2011). Consequently, this study viewed that children beyond control in Malaysia are similar to status offenders since they commit non-criminal behaviour. This is evidenced from the division of children categories made by the Child Act 2001 (and upheld by the Child Act (Amendment) 2016) which separates children beyond control from children in need of care and protection, and children who commit crimes. The children beyond control category is placed under its own division, namely Part VII under the title of "Beyond Control" which comprises of sections 46 and 47 with its own procedure and types of orders. This status is supported by the Department of Social Welfare when it explains beyond control behaviour as behaviour which may cause crime or moral danger (Jabatan Kebajikan Masyarakat Malaysia, n.d.) and many previous local studies which equated such behaviour with status offence (Ahmad, 2013; Dusuki, n.d; Zakaria, 1996; Child Rights Coalition Malaysia, 2012; Hussin, 2012).

\section{Institutionalization Of Children Beyond Control Under Previous Legislations}

This study found that rehabilitation of children beyond control today under the Child Act 2001 differs from the previous practice. Rehabilitation of children during British period focused on detention in institutional settings. Section 18(2) of the Ordinance No. 47 (Reformatories and Industrial Schools) gave the jurisdiction to the court to order either (i) to detain the children in institutions approved by the Governor, or (ii) to send them to Certified Industrial School or Reformatory School. Certified Industrial School refers to any school or institution certified by the Governor under the Ordinance (section 2) while Reformatory School is any school established by the government under the Ordinance and gazetted for the purpose of reformation of children offenders (sections 2 and 11).

The Juvenile Courts Act 1947 passed afterwards started to give choices to the court either to send the children beyond control to the rehabilitative institutions or place them under the supervision of probation officer. However, the institutional placement remains dominant since it was placed as the first order which may be made by the court and comprised of several selections of institutions. Section 37 provides that the children may be institutionalized either in the approved schools, Henry Gurney Schools, or any institutions approved by the Minister. Apart from that, those who were put under supervision may also be sent to institution (probation hostels) for not more than 12 months as 
an additional order. In addition, the supervision order may be amended by the court where the children may either be sent to the institutions or placed in the care of fit persons.

About 54 years later, the Child Act 2001 was passed. It maintains both types of rehabilitation previously made by the Juvenile Courts Act 1947, namely the placement in institutions and supervision. Section 46 only amends the types of institutions which may accommodate children beyond control. It excludes Henry Gurney School from the list of institutions and includes probation hostels (Asrama Akhlak), places of refuge (Taman Seri Puteri) and private homes called "centre" (Pusat) besides maintaining the approved schools (Sekolah Tunas Bakti) as institutional alternatives. The provisions relating to the order of supervision by the probation officer remains the same as previously enacted. Therefore, there is not much change made by the Child Act 2001 pertaining to the types of order made by the court whereby institutionalization remains the main choice of order. In fact, according to the respondents, institutions play an important role in rehabilitating children beyond control. Some of the reasons laid down by them are that institutional placement may prevent the children from continuing their misbehavior usually committed at home or from negative influence found outside of the institution, has the disciplinary and spiritual elements, may make the children realize of their mistakes, may improve family relationship due to the separation of children from their family, able to control the children's movements, and enable the children to participate in various beneficial activities.

\section{Why Deinstitutionalisation?}

Problems pertaining to the suitability or relevancy of institutional placement of the children beyond control have been raised in the report submitted by the Committee on the Rights of the Child in 2007. Malaysia was urged to review section 46 of the Child Act 2001 in order to abolish the detention of the children in institutions (Committee on the Rights of the Child, n.d.). However, the Child Rights Coalition Malaysia reported five years later that the children are still brought to the institutions and subjected to the same treatment as those who commit crimes (Child Rights Coalition Malaysia, 2012). The issue continued when the Child Frontiers reported similar situation in 2013 (Child Frontiers, 2013). It observed that the Convention on the Rights of the Child's principle in placing the institutional placement as the last resort was not consistently followed. Thus, Malaysia was suggested to make a holistic reformation to its children justice system by applying diversion programmes and abolishing institutional placement. The court should not be involved in handling family problems like truancy, running away from home or other parent-child relationship problems. According to Child Frontiers' research outcome, institutional treatment is not suitable for rehabilitation of children beyond control because such case encompasses family problem. The placement may cause them to act rebellious and deteriorate family relationship which would interrupt the reintegration process. Besides that, most of the institutional rehabilitation approaches were based on standard discipline, religious order and vocational training which were similar to those practised in Henry Gurney School under the Prison Department. There was no individual assessment or care plan, and all children in the institutions follow the same standardised programme in daily routine. The placement of children beyond control in the same institution which places children who commit crimes was also criticised by Abdul Hadi (1996) because they were subjected to the same treatment. In this situation, children 
beyond control who are usually younger and less matured will learn worse behaviour from other children in the institutions (Child Frontiers, 2013). Moreover, the exposure of children beyond control to criminal influence and the close relationship with those who commit crimes will affect their social behaviour and psychology (Champion, 2007).

The negative impact of institutional placement cannot be denied. England and Wales for instance, had witnessed the court's involvement worsens the children's condition. The increasing of illtreatment in institutions was seen as "incredibly bleak and depressing picture which is a national disgrace" (Herring, 2011). The children have a bad start in life when the progress statistics showed a lower satisfaction in terms of academic achievement, health, positive activity and carrier aspect. Similar situation had occurred in United States of America earlier which led to the formation of "deinstitutionalisation of status offences" policy through the Juvenile Justice and Delinquency Prevention Act 1974 to prevent status offenders from being institutionalised together with the children who commit crimes (Champion, 2007). The unsuitability of institutional placement is also supported by the international standard when it lays down that deprivation of liberty may occur in any types of institution whether the institution is specialised for those who commit crimes only, for improving behaviour, for educational purpose or for protection (Nayagam, 2009).

Besides that, the function of institutional placement order also has to be reconsidered in the context of paradigm shift occurred in the children justice system. The widely practised retributive justice is now shifting towards restorative justice with the aim to restore justice by providing problem solving through specified methods like diversion programmes, mediation, discussion, and society programmes (Special Representative of the Secretary-General on Violence Against Children, n.d.). Diversion means the shifting of cases from formal court process towards community-based rehabilitation to avoid negative effect caused by such procedure (Nayagam, 2009). Cantwell (1998) enlightens that the pre-institutional diversion is appropriate for the first-time offenders or those who commit non-serious misbehaviour in order to avoid them from unnecessary involvement with the court. Thus, restorative justice principle should be applied in beyond control cases since it supports rehabilitation in family and society environment. Institutional placement should be set aside or at least placed as the last resort after all other alternative treatments failed. In this context, according to Ellis and Sowers (2001), institutional placement can only be ordered if the safety of the society is more important than the children's rehabilitation. Similarly, Cantwell (1998) viewed that freedom restriction should not be imposed unless the objective of the order is not met through non-detention measures. The European Convention stresses that institutional placement needs justification because the transferring of the children from their families is an intervention that encroaches the rights of both parents and children to enjoy family life (Herring, 2011). The United Nation Standard Minimum Rules for the Administration of Juvenile Justice (Beijing Rules) and the Convention on the Rights of the Children also supports that placement in institutions should be the last resort and imposed for the shortest period (Cantwell, 1998). As an alternative, these international standards suggest several rehabilitative orders such as care and supervision order, supervision order, community service order, monetary penalty, compensation, counselling, foster care order and other educational measures. 


\section{The Effect of the Child Act (Amendment) 2016 on Institutionalization of Children Beyond Control} On 1st January 2017, the Child Act (Amendment) 2016 came into force with the purpose to improve the protection and welfare aspects of the children in Malaysia. In terms of children beyond control, the amendment introduces family-based care to support the development and well-being of the children (Child Act (Amendment) Bill, 2015). The members of the family are required to involve in the rehabilitation process of the children to support its success. According to the respondents, the amendment also reorganizes the placement of the children in the Department of Social Welfare's institutions. Each of the institutions has its own specialisation and only accommodate specific category of children without mixing them with other category of children, for example, the children beyond control would not be placed with children who commit crimes in a same institution. As a result, children beyond control may only be placed in the probation hostels to provide more effective rehabilitation process.

Section 46(5) of the Child Act (Amendment) 2016 provides that the Court for Children has to consider family-based care before making any order. In light of this concept, the court is given the jurisdiction to order a beyond control child either to be (i) placed in the care of a fit and proper person and supervised by probation officer, (ii) placed in a center and supervised by probation officer, (iii) detained in a probation hostel and supervised by probation officer, or (iv) placed under the supervision of a probation officer. Compared to the previous provisions, the court now has four different choices of order including one detention in institution and it may not order for detention in the approved school and place of refuge anymore. Instead, the court has to give priority to place the child in the care of a fit and proper person who would normally be the child's own relatives. The exclusion of these children from the approved schools also means that they may not be brought to Henry Gurney School anymore on the ground of escaping from the approved schools. Apart from the orders made against the children, in order to emphasize on the responsibility of the parents towards their children, the court may also make parental orders. The parents may be directed to fulfill certain conditions such as to visit their children on a regular basis, to attend interactive workshops together with their children and to attend counselling sessions together with their children (section 46(7)). Failure to fulfill such conditions would make the parents liable for an offence and may be fined up to RM5,000 (section 46(8)). This amendment clearly shows the government's intention to reduce the placement of children beyond control in institutions in support of the Convention on the Rights of the Child's principle to protect their best interest. It is confirmed by the respondents who explained that the amendment made to the children beyond control's provisions is a step towards deinstitutionalization.

\section{Conclusion}

The above discussion shows that deinstitutionalisation is not new in Malaysia. Steps taken towards it may be seen when the institutional placement of the children is suggested to be the last resort in rehabilitation during the drafting of the Juvenile Courts Act 1947. Despite the national policy and international law guidelines, this study found that the legislators seemed to prioritise institutional placement in drafting the children beyond control provisions. Institutions were placed on top of the list of orders which may be made by the court compared to other alternatives like supervision, placed 
in the care of a fit person or sent to centre. This situation was in fact worsened by the believes of those who directly involved in the rehabilitation process of the children that the institutions are suitable and effective method of treatment. As a result, most of children beyond control were sent to the institutions for rehabilitation and treated similar to those who commit crimes.

Nevertheless, a significant change has been made recently to the children beyond control provisions in the Child Act 2001 through the Child Act (Amendment) 2016. The introduction of family-based care concept has minimised the function of institutional placement and thus forms a big step towards deinstitutionalisation. The court is urged to apply family-based care concept by placing the children in the care of fit and proper persons or sending them to a centre. The children may only be brought to one institution, namely the probation hostels with specialised treatment whereby they will not be mixed with those who commit crimes anymore. However, the authors viewed that before making the institutional placement order, the court has to show a strong justification to support 'the last resort principle' for the best interest of the children. It is hoped that deinstitutionalisation of children beyond control becomes a reality in order to improve the children's misbehaviour, strengthen the parent-child relationship, and instil responsibility in the members of the family and society as a whole. On top of that, deinstitutionalisation is the best step to prevent the children from committing worse behaviour or being involved in crimes.

\section{Corresponding Author}

Shariffah Nuridah Aishah Syed Nong, PhD student, Faculty of Law, University of Malaya, 50603, Kuala Lumpur, Malaysia \& Senior Lecture, Faculty of Law and International Relations, Sultan Zainal Abidin University, 21300, Terengganu, Malaysia

Email: aishah@unisza.edu.my

\section{References}

Age Discrimination: Global Report on Status Offences. (2009). Retrieved 15 September 2017, from www.crin.org/en/library/publications/age-discrimination-global-report-status-offences-2ndedition.

Ahmad, N. (2013). The Unheard Voices of Child Offenders: Time for Reform for the Youth Justice System in Malaysia? Presented at the 6th World Congress on Family Law and Children's Right, Sydney, Australia on 17-20 Mac 2013. Retrieved 11 January 2014, from www. lawrights.asn.au/6thworld-congress/papers.html.

Akram, M. (2007). A Study on Some Recent Developments in the Rising Rate of Delinquent Behaviour in Malaysia. Malayan Law Journal, 7, xxxvii.

Cantwell, N. (1998). Juvenile Justice. Innocenti Digest, 3, 1-24. Retrieved 23 August 2016, from https://www.unicef-irc.org/publications/pdf/digest3e.pdf

Champion, D. J. 2007. The Juvenile Justice System: Delinquency, Processing, and the Law. 5th ed.. New Jersey: Pearson Education Inc. 
INTERNATIONAL JOURNAL OF ACADEMIC RESEARCH IN BUSINESS AND SOCIAL SCIENCES Vol. 9, No. 3, March, 2019, E-ISSN: 222 2-6990 ¿ 2019 HRMARS

Ellis, R. A., \& Sowers, K. M. (2001). Juvenile Justice Practice: A Cross-Disciplinary Approach to Intervention. United States of America: Wadsworth Thomson Learning, Inc.

Haji Ali, A. (2006). Salah Laku Sosial Remaja Masa Kini: Cabaran dan Penyelesaiannya. In Institusi Keluarga: Menghadapi Cabaran Alaf Baru (pp. 89-115). Kuala Lumpur: Utusan Publications.

Hamzah, H., Mustafa, J., \& Che Din, M. F. (2011). Masalah Sosial Remaja Masa Kini. Kuala Lumpur: Institut Sosial Malaysia.

Herring, J. (2011). Family Law. 5th ed. England: Pearson Education Limited.

Hussin, N. (2012). Juvenile Delinquency in Malaysia: Legal Framework and Prospects for Reforms. IIUM Law Journal, 15(2), 197-214.

Kim, J. J. (2010). Left Behind: The Paternalistic Treatment of Status Offenders Within the Juvenile Justice System. Washington University Law Review, 87, 843-867. Retrieved 7 November 2014, from http://www.lexisnexis.com/Inacui2api/api/version1/getDocCui?Ini=505G-5NY0-00CW-

303P\&csi $=27094$ 4,270077,11059,8411\&hl=t\&

$h v=t \& h n s d=f \& h n s=t \& h g n=t \& o c=00240 \&$ perma $=$ true.

Matthews, H. T. (2000). Status Offenders: Our Children's Constitutional Rights Versus What's Right For Them. Southern University Law Review, 27, 201-213. Retrieved 7 November 2014, from http://www.lexis nexis.com/Inacui2api/api/version1/getDocCui?Ini=42D8-GV70-00CVD0GC\&csi=270944,270077,11059,8411\&hl=t\&hv=t\&hnsd=f\&hns=t\& hgn=t\&oc $=00240 \&$ perma $=$ true.

Nayagam, J. (2009). Strengths and Weakness of the Protection Mechanism and Support System for Reintegration of Children in Conflict with the Law [Human Rights and the Administration of Justice: A Report of SUHAKAM's Conference held in Conjunction with the $8^{\text {th }}$ Human Rights Day 9 September 2008], Retrieved 15 January 2014, from http://www.suhakam.org.my/c/document_library/get_file?p_1_id=22118_\&_folderld =64628 \& name=DLFE-5601.pdf.

Rashid, M. Z. (2009). Juvenile Justice in Malaysia: Role of the Department of Social Welfare [Human Rights and the Administration of Justice: A Report of SUHAKAM's Conference held in Conjunction with the 8th Human Rights Day 9 September 2008]. Retrieved 15 January 2014, from http://www.suhakam.org.my/c/document_library/get_file?p_1_id =22118_\&_folder Id $=64628$ \& name=DLFE-5601.pdf.

Report of the Juvenile Delinquency and Juvenile Welfare Committee. (1947). (No. 18, M.U. 3484/47) (pp. c289-c300). 
INTERNATIONAL JOURNAL OF ACADEMIC RESEARCH IN BUSINESS AND SOCIAL SCIENCES

Vol. 9, No. 3, March, 2019, E-ISSN: 222 2-6990 @ 2019 HRMARS

Sushama, P. C. (1992). The Caring Society: Institutional History and Prospects. In Caring Society: Emerging Issues and Future Directions (pp. 55-73). Malaysia: Institute of Strategic and International Studies.

Triantafillou, P., \& Moreira, A. (2002). Rehearsing Citizenship: The Governing of Juvenile Delinquency in Colonial Malaya. Citizenship Studies, 6 (3), 325-340. Retrieved 9 November 2016, from http://dx.doi.org/ 10.1080/1362102022000011649.

Villarante, A. J. (2005). A Comparative Study of Juvenile Justice Systems in Japan and Malaysia: A Review of Policies, Approaches and Strategies. In Economic Prospects, Cultural Encounters and Political Decisions: Reconstructing Scenes in a Moving Asia (East and Southeast) (pp. 90-106).

Tokyo: The Nippon Foundation, Asian Public Intellectuals Program. Retrieved 19 January 2015, from http://scholar.google.com.my/

scholar?hl=en\&q=A+Comparative+Study+of+Juvenile+Justice+Systems+in+Japan+and+Malaysia\%3A $+A+$ Review+of+Policies\%2C+Approaches+and+Strategies\&btnG=\&as_sdt=1\%2C5\&as_sdtp=.

Yahaya, A., Yahaya, N., \& Bachok, J. J. @ D. J. (2010). Perkaitan Antara Hubungan Kekeluargaan, Pengaruh Rakan Sebaya dan Kecerdasan Emosi dengan Tingkah Laku Delinkuen Pelajar Sekolah Bestari di Daerah Pontian. Retrieved 12 September 2014, from http://eprints.utm.my/10118/.

Zakaria, A. H. (1996). Institutional Care of Minors: A Discussion of Some Preliminary Issues. In A Collection of Socio-Legal Essays (pp. 89-117). Kuala Lumpur: Universiti Malaya Press. 